\title{
Garudwara Reform Movement1920- 1925
}

\author{
Dr. Rakesh kumar \\ Lect In Deptt Of History G.S.S.S Dhanoor, Sirsa,Haryana, India
}

\begin{abstract}
The Akali movement of twenties which originated as purely religious movement for reform of Gurdwaras, the Sikh religious shrines, soon acquired a political character and became part and parcel of India's freedom struggle. Besides being anti-imperialist ${ }^{l}$ Akali movement variously known as Gurdwara reform movement or Gurdwara agitations how Sikh"s long dawn campaign in the early twenties of the twentieth century for the liberation of their Gurudwara or holy shrine is described. The campaign which elicited enthusiastic support, especially, from the rural masses, took the form of a peaceful agitation marches, divans or religious gathering, and demonstration for Sikhs to assert their right to manage their place of worship. Ultimately, the government had to bow to popular pressure and allow the Sikhs to take over the management of their shrines, the Gurudwara act passed in 1925 made the SGPC, a representative body of Sikhs, custodian of all important Sikh places of worship ${ }^{2}$.

Key words: Akali, Movement, Gurdwara, reform, religious, S.G.P.C
\end{abstract}

\section{Introduction:}

The establishment of Shiromani Gurdwara Parbandhak Committee and Shiromani Akali Dal in December 1920 heralded a new era in the history of Punjab politics. The Gurdwara Reform Movement was started by Sikhs to free their Gurdwaras from the control of Mahants (Priests). Gurdwaras are the places for worship for the Sikhs. In the early days Gurdwaras were simple Dharmsalas. But with the passage of time these Dharmsalas became a centre of Sikh community, where, apart from worship and religious ceremonial activities connected with births, baptisms, betrothals, marriages and obsequies were observed. There was a free kitchen, the Guru-Ka-Langar, and also a school (Pathshala) where children learnt the alphabet and their daily Prayer ${ }^{3}$ These Dharmsalas were later called Gurdwaras. In other words the Dharmsalas or Gurdwaras were the important institution of the Sikhs. According to Sikh tradition the priests in the early days as well as other persons were placed in-charge of various Gurdwaras. It was in tune with the advice of Guru Nanak. Moreover, they ${ }^{4}$ wished to dedicate their life to prayer and service of the community.3Moreover some of them had been leading luxurious life and squandered large earnings of Gurdwaras on wine and women ${ }^{4}$.

Objectives

1.TO Analyse background of the Akali movement.2.TO Analyses main Jaitha's launched by Akali.

3.To Analyses British view towards Akali movement.4.To conclude the movement.

1.SinghHari,(1984)Master Punjab Peasant in Freedom Struggle, volume two.pph New Delhi,P106

2Brar.JS,(1989)The Communist Party in Punjab,National Book Organisation,NEW Delhi,p-27

3(Khushwant Singh, A History of the Sikhs, Vol. II, Oxford University Press, Bombay,1966, p. 194.)

4 Proceedings Home Political, No. 942/1922 (N.A.I).

The Gurdwara Reform Movement is significant in three respects (1) It created sense of confidence among the Indians that the British could be forced to meet their genuine demands through non-violent mass movement; (2) it brought the Akali Dal and the Congress leadership very close to each other, giving a great impetus to the freedom movement in Punjab; (3) the Shiromani Gurdwara Prabandhak Committee and the Akali Dal provided the institutional and organizational structure to respond to the aspirations of the newly mobilized Sikh masses, and in the process it acted as the training ground for the emerging $\mathrm{Sikh}^{5}$

Gurdwara_Reform_MovementIn the course of their five year (1920-25) struggle the Shiromani GurdwaraPrabandhak Committee and the Akali Dal were not only able to oust the Mahants rather obtained the control over all the important Sikh shrines through peaceful agitation and passive sufferings, but also to strengthen the forces of nationalism in the Punjab by ejecting the Mahants, the government appointed managers and other vested interests in the Sikh communities. Once the important Sikh shrines came under the Akali control, the Mahants in charge of the smaller Gurdwaras either voluntarily submitted to the authority of the Shiromani Gurdwara Prabandhak Committee or were made to surrender their shrines and the jagirs attached to them under the provisions of the Sikh Gurdwaras and Shrines Bill passed in July 1925. Mohinder Singh opines that over three hundred large and small Gurdwaras were liberated by the Akali ${ }^{6}$ 
Daily Akali Founded-A daily Punjabi newspaper Akali was brought out from Lahore on 11november1920, as a result of efforts of Harchand Singh and Master Sunder Singh of Lyallpur. The Akali in its very first issue propounded the following programme for the Akali movement:

1. To bring Gurdwaras under democratic control of Sikhs.

2. To bring khalsa college, Amritsar, also under democratic control of Sikhs.

3. Reconstruction of the wall of Gurdwara Rikabganj, Delhi

4. To create political awaking among Sikhs and arouse them to participate in national freedom struggle.

5. To set up an organisation of Sikhs on democratic basis.

As a result of propaganda carried on by the Akali, Akali jatha sprung up in town and village. Member of these jatha wore black turban turban, carried kirpan and took the pledge to make all sacrifices for the sacred cause of liberation of their gurdwaras ${ }^{7}$.

\section{GurdwaraBabe-di-Ber}

Chronologically the first Gurdwara to be reformed through agitation was Babe-di-Ber Sialkot. When Hamam Singh, its Mahant died. His widow had her minor son appointed as successor, under .The guardianship of one Ganda Singh, an Honorary Magistrate. There was a wave of resentment among the Sikhs thought out the Punjab against this action. And various Singh Sabhas sent telegrams to the Lieutenant-Governor of the Panjab conveying their protest- against this 'outrage' the collector, however, decided to ignore all popular opposition and sanctioned the mutation in favour of the minor Mahant Gurcharan Singh. The reformers reacted by filing a civil suit in the court of the District Judge who ordered the plaintiffs to pay a court fee of Rs.50,OOO

5. Proceedings Home Political, No. 942/1922 (N.A.I).

6. Singh Mohinder,(1988) The Akali Struggle, Retrospect,Atlantic pub,New Delhi p. 19, 20.

7. Singh Hari,Master Punjab Peasant in Freedom Struggle, volume two.pph New Delhi1984P106

by 30August 1920. As the reformers could not collect such a huge amount, their complaint was rejected. Having thus failed to achieve their objective through recourse to be courts, the reformer then resorted to peaceful agitation. The Sikhs of the locality organised, themselves and formed a Khalsa Sewak Jatha to reform the Gurdwaras in the city. Under the new programme of action, they started holding weekly (and latter daily)services in the Gurdwara Ganda' Singh placed many hurdles in. the way of the reformers., but they succeeded in taking over the control of shrine and re-starting the system' of free langar which had been stopped by the Mahant .On 5 October 1920, the Sikhs held a big elected 8 managing committee of 13 members for the control of the Gurdwara .Mean while some new' developments in the affairs of the Golden Temple and the Akal Takhat diverted the attention of the reformers and the (of struggle shifted from relatively small town to the. Sikh headquarters at Amritsar ${ }^{8}$

The Nankana Holocaust It was being manage by an udasi mahant, narain das, who lived in the Gurdwara with a mistress and was known to haveinvited prostitute to dance in the sacred premises.local Sikhs theredtended to eject him by force the mahant asked the police for and hired nearly 400 things to safeguards and defend his interest in early morning hours on 20, Feb.1921, a jatha(band) of akali led by lachman singh Dharovalia entered the gurdwara. The gates of shrines were then closed,and Narain Das thungs attacked the Jatha with swords, hatches, and firearms. The dead and dying Akalis were then dragged to a pile of legs which had been cololected earlier, and burnt by the time. The police and local Sikhs came on the scene $130 \mathrm{men}$ had been consumed by flames ${ }^{9}$. Nankana Sahib Tragedy was the most important tragedy of the Gurdwara reform movement, which infuriated the whole Indian people against the priests of Gurdwara and the Government ${ }^{10}$ Only a boy of 12 years, who had taken refuge under Guru Granth Sahib, was spared. The news of the outrage spread like wildfire. Sardar Uttam Singh wired the terrible news to the Governor, the Commissioner the Deputy Commissioner, the Superintendent of Police and different Sikhs centres Teja Singh, Gurdwara Reform Movement and the Sikh Awakening, p. 238 Bands of Akalis from distant towns began to converge on Nankana. The Deputy Commissioner Currie reached Nankana Sahib at 12:30 p.m. he could do nothing without the assistance of Police and saw the bodies of Sikhs burning with his own eyes ${ }^{11}$

\section{Gurdwara Gangsar at Jaitu}

In 1923, the Akalis decided to take over the Gurdwara Gangsar at Jaitu (or Jaito) in the Nabha State. The erstwhile Maharaja (ruler) of Nabha Ripudaman Singh had been sympathetic to the Akali and the Indian nationailst cause, but was deposed by the British Government. ${ }^{12}$

When the SGPC launched an agitation, its leaders and members were arrested on the charge of sedition. Subsequently, several marches were organized in support of the agitation. The protestors were arrested, beaten and shot at by the police at various instances. 
8.SinghMohinder,(1977)The Akali Movement, National Institute Of Punjab Studies New Delhi,P 19,20

9.Singh Khushwant(1966), A History of the Sikhs, Vol. II, Oxford University Press, Bombay, p. 199

10.Singh Giani Partap, Gurdwara Sudhar Arthat Akali Lehar, p. 113

11. Sohan Singh Josh,(1977) Akali Morchian Da Itihas,Aarsi pub,Delhi pp. 70-71.

12.Surinder Singh Johar (1998). Holy Sikh Shrines. M.D. PublicationsNew Delhi. p.64.

The Indian National Congress declared its support for the Akali agitation in at the special Congress Session in Delhi ${ }^{13}$ The Akalis were then joined by several non-Sikhs, including Jawaharlal Nehru (later the first Prime Minister of India) and Kasturiranga Santhanam.Nehru ${ }^{14}$ and others were arrested during one such march. ${ }^{15}$ Finally, the Government of Punjab relented and agreed to transfer the control of the gurdwara to the Akalis.

While the Jaitu agitation was on, the Akalis also sought the control of the gurdwara at Bhai Pheru. The gurdwara was controlled by Udasi mahants including Pala Ram, the brother of Narain Das (who was responsible for the Nankana massacre). The mahant agreed to transfer the control of the gurdwara to SGPC, after being offered a pension. However, in August 1923, when the Akalis decided to eject the Udasi tenants housed in the gurdwara premises, they faced considerable resistance. On 4 December 1923, a group of Akalis damaged a mahant's residence attached to the shrine. The police arrested 11 Akalis following a complaint ${ }^{16}$. In S.C.Mittal (1977). Freedom Movement in Punjab. Concept. pp. 171-179.

December, the Government recognized the SGPC as the manager of the gurdwara, but also ordered the Akalis to follow the legal process for ejecting the Udasi mahants out of the premises. On 1 January 1924, an Akali jatha forcibly took the possession of the property occupied by Pala Ram. Around 34 Akalis were arrested by the police for this action on the next day. In subsequent days, a number of Akali jathas staged demonstrations at the site. A total of 5,251 persons were arrested for the demonstrations, and 3,092 of these were sent to the prison ${ }^{17}$.

Morcha For Keys

with the setting up SGPC,There was improvement in the management of Darbar Sahib,Sarbrah Sunder Singh Ramgarhia was cooperating with the committee.on 20 april1921, it had been declared by the government that it had handed over management of darbar sahib to the Sikhs.but keys of toshakhana were still in possession of government-appointment sarbrah.lest the latter hand over keys to SGPC,DEPUTY COMMISSIOR,Amritsar,sent EAC Amar Nath to secure keys from the Sarbrah.the keys were placed in the government treasure. this foolish act of the deputy commissioner proved that the statement of the government that management of darbar sahib had been handed over to Sikhs was false.government was further isolated among the Sikhs. the hands of non-cooperator were strengthened.the SGPC held a meeting and passed a resolution to boycott the forthcoming visit of prince of wales to Punjab.the Sikhs shope-keepers were called upon to observe hartal on that day along with their hindu and Muslim brethren.it was further decided by the committee that by way of protest there would be no illumination on 15 Novembr,the birthday of Guru Nanak. ${ }^{18}$

to protect against the government action the government action,aa massive public meeting was held in Bagh Akaliion.Akalis from all over the Punjab had arrived to take in the protest Dewan,5000 of them having already arrived by afternoon of 11 November 1921 .

13 Bakhshish Singh Nijjar (1996). History of the United Panjab. Atlantic Publishers \& Dist. p. 130

14. S C Mittal (1977). Freedom Movement in Punjab. Concept. pp. 171-179.

15 Surinder Singh Johar (1998). Holy Sikh Shrines, M.D. Publications New Delhi p. 64.

16. S C Mittal (1977). Freedom Movement in Punjab, Concept.Anand Nagar Delhi p. 171-179.

17 S C Mittal (1977). Freedom Movement in Punjab. Anand Nagar Delhi Concept pp. 171-179.

18 Singh Hari,Master Punjab Peasant in Freedom Struggle,volume two.pph New Delhi1984P112-113

the main speakers at the meeting were kharak singh,Jaswant Singh Jhabal and Mehtab Singh. ${ }^{19}$

Meanwhile the government had appointed another Sarbrah,Captain Bahadur Singh of Ghwind in place of Sunder Singh Ramgarhia,He was a toady who in 1915 had helped the government to arrest

a patriot Ganga Singh in Hoti Mardan. the deputy commissioner handed over keys to him.on 12 november1921,SGPCtook the decision to boycott the new Sarbrah Sahib.such was the prevailing sentiment among Sikhs masses that soon the new Sarbrah also resigned and apologised to the SGPC. ${ }^{20}$

\section{At Guru-ka-Bagh}

At Guru-ka-Bagh, twenty kilometres from Amritsar, Sikhs' capacity forsuffering and resistance was put to further trial after freeing many Gurdwaras through peaceful resistance. Sundar Das, the mahant, had by mutual negotiations made over the shrine to the Shiromani Committee, taken the Sikh baptism and parted with his mistresses except one whom he honourably married. But he later repudiated part of the agreement, saying that, though he had surrendered the gurdwara to the Shiromani Committee, the piece of land known as Guru-ka- 
Bagh attached to it was still his property. He objected to Sikhs cutting down trees on that land for the langar. The police, willing to oblige him, arrested on August 9, 1922, five Sikhs on charges of trespass. These arrests were made not on Sundar Das' complaint, but on a confidential report received by the police. The following day, the arrested Sikhs were hurriedly tried and sentenced to six months' rigorous imprisonment. ${ }^{21}$

Undeterred by this action of the government, Sikhs continued the old practice of hewing wood from Guru-ka-Bagh for the daily requirements of the community kitchen. The process of arrests and convictions proving of little avail, police tried a new technique to terrorize the reformers. Those who came to cut firewood from Guru-ka-Bagh were beaten up in a merciless manner until they lay senseless on the ground. They were dragged about by their hair and left contemptuously off when the police thought they had been served well enough. The Sikhs sutfered all this stoically and went in larger numbers day by day to submit themselves to the beating. From August 31, the number was raised to 100. Every day a batch of one hundred volunteers would start from the Akal Takht pledged to suffer their fate silently. The police would stop them on the way and smite them with heavy brass-bound sticks and rifle-butts. The belabouring continued until the batch lay prostrate to a man. The Sikhs displayed unique powers of self-control and resolution, and bore the bodily torment in a spirit of complete resignation. None of them winced or raised his hand. ${ }^{22}$

The Governor of the Punjab visited Amritsar on September 13, 1922, and stopped the beating of Sikh volunteers. Arrests began to be made instead. At the government announcement that preparations were being made to accommodate ten thousand Akalis in gaols, the Sikhs stepped up their campaigm. Jathas grew larger in size. The government at last gave in. The offices of Sir Ganga Ram, a rich and influential citizen of Lahores were secured. On November 16, 1922, he obtained the Guru-ka-Bagh land on lease from the mahant.

19.Singh Hari,Master Punjab Peasant in Freedom Struggle,volume two.pph New Delhi1984P112-113

20.Singh Hari,Master Punjab Peasant in Freedom Struggle,volume two.pph New Delhi1984P112-113

21. Harbans Singh "The encyclopedia of Sikhism.

22. Harbans Singh "The encyclopedia of Sikhism.

and wrote to government that he required no police protection. The government had the excuse not to interfere with the Sikhs who could now go unmolested to Guru-ka-Bagh to cut wood in the jungle. The Sikhs' gain was not confined merely to the immediate point involved. The moral implication of the issue was far more important. ${ }^{23}$ Harbans Singh "The encyclopedia of Sikhism.

\section{Babar Akali}

The Nankana massacre and the behaviour of the police at Guru ka Bagh induced some to organize an underground terrorist movement.

These terrorists, who called themselves Babar (Lion) Akalis, were largely drawn from the Ghadr party and army soldiers on leave. Babar violence was, however, of short duration. By the summer of 1923, most of the Babars had been apprehended. The trial conducted in camera began inside Lahore Central Jail on 15 August 1923 and was presided over by an English judge.Of the 91 accused, two died in jail during trial, 34 were acquitted, six including Jathedar Kishan Singh Gargajj, were awarded death penalty, while the remaining 49 were sentenced to varying terms of imprisonment ${ }^{24}$.

At the same time Malcolm Hailey, the governor of the Punjab showed his readiness to assist the Sikhs in taking possession of all the important Gurdwaras in the province through a five-member committee constituted by the Sikh members of the legislative council. Hailey presented a draft of a new Gurdwara Bill to the Akali leaders imprisoned in Lahore fort. Master Tara Singh, Bhag singh Advocate, gurcharn singh Advocate, Teja Singh Akerpuri(Jathedar AkalTakht Sahib) Sohan Singh Josh and Sardar Teja Singh Samundri studied each clause of the bill carefully. The bill met all the Akali demands and was passed into law on July 28 , 1925 by the Governor General of India after its ratification by the Punjab legislative council. The Act came into force on November 1, 1925 with a gazette notification from the government of Punjab. According to the Act a Central Gurdwara Board elected by the Sikhs was to be the custodian of all-important Sikh places of worship. The first meeting of the Gurdwara board passed a resolution that its designation be changed to Shiromani Gurdwara Parbandhak Committee, which was accepted by the government. ${ }^{25}$ Thus ended what came to be known in common parlance as the 'Third Sikh War'. The Punjab government withdrew its orders declaring the Shiromani Gurdwara Parbandhak Committee and other Akali organs as unlawful associations and recognized the Shiromani Gurdwara Parbandhak Committee as a representative body of the Sikhs. In making the Punjab government agree to such recognition, the Akali leadership undoubtedly scored a victory over the bureaucracy. The Sikh Gurdwara bill met most of the demands of the Sikhs, but the government was willing to release the prisoners conditionally i.e. on the understanding to be given by the Akalis that they would agree to work for the Gurdwara Act. The Shiromani Akali Dal and the executive declared conditions imposed for the release of prisoners as wholly unnecessary, unjust and derogatory. ${ }^{26}$ Among the prominent Akalis, Mehtab Singh and Giani Sher Singh along with twenty other Akali leaders accepted the conditional release. Master Tara Singh, Bhag Singh Advocate, Teja Singh Samundari, Teja singh Akerpuri (Jathedar Akal Takht)and Fifteen other 
Akalis did not come out as government emphasis on eliciting written assurance and acceptance was to Master Tara Singh, an attack on the self-respect of the Sikhs. He said, "We ourselves have enacted this Act and we are responsible for implementing it, then why this condition?"

23.Harbans Singh "The encyclopedia of Sikhism.

24.AKALIMOVEMENTCategory:Sikhreformistmovements(SikhEncyclopedia)http://www.thesikhencyclopedia .com

25. Shiromani Gurdwara Parbandhak Committee From Wikipedia, the free encyclopedia

26. Shiromani Gurdwara Parbandhak Committee From Wikipedia, the free encyclopedia

Teja Singh Samundari died of a heart attack in the jail after some time. The Punjab Government failed to prove the charges against Master Tara Singh and the remaining Akalis, few months later they all were released unconditionally. The courage and sacrifice shown by the Akalis during the trial very soon drove the Mehtab Singh's group out of the political field and led to a rift in the Akali ranks, as the newly released Akalis condemned Mehtab Singh's group as collaborators. Mehtab Singh's group was also known as 'Rai Bahadur Party'. This group had majority in the committee and Mehtab Singh was elected its President. The Akali Party launched a campaign against the conditionally released leaders. When the new elections for the Shiromani Gurdwara Parbandhak Committee were held, the Akali Party won majority and the newly elected Shiromani Gurdwara Parbandhak Committee elected Kharak Singh as the President and Master Tara Singh as the Vice President. Since Baba Kharak Singh had not yet been released the responsibility of the president fell on the shoulders of Master Tara Singh ${ }^{27}$.

\section{Conclusion}

Gurdwara_Reform_MovementIn the course of their five year (1920-25) struggle the Shiromani GurdwaraPrabandhak Committee and the Akali Dal were not only able to oust the Mahants rather obtained the control over all the important Sikh shrines through peaceful agitation and passive sufferings, but also to strengthen the forces of nationalism in the Punjab by ejecting the Mahants, the government appointed managers and other vested interests in the Sikh communities. Once the important Sikh shrines came under the Akali control, the Mahants in charge of the smaller Gurdwaras either voluntarily submitted to the authority of the Shiromani Gurdwara Prabandhak Committee or were made to surrender their shrines and the jagirs attached to them under the provisions of the Sikh Gurdwaras and Shrines Bill passed in July 1925. Singh Mohinder Opines that over three hundred large and small Gurdwaras were liberated by the Akalis ${ }^{28}$

27. Shiromani Gurdwara Parbandhak Committee From Wikipedia, the free encyclopedia 28.Singh Mohinder, (1988)The Akali Struggle, Retrospect,Atlantic publisher,New Dehi p. $19,20$.

\section{References}

[1]. SinghHari,Master Punjab Peasant in Freedom Struggle, volume two.pph New Delhi1984P106

[2]. Brar.JS,(1989)The Communist Party in Punjab,National Book Organisation,NEW Delhi,p-27

[3]. Khushwant Singh, A History of the Sikhs, Vol. II, Oxford University Press, Bombay,1966, p. 194.)

[4]. Proceedings Home Political, No. 942/1922 (N.A.I).

[5]. Proceedings Home Political, No. 942/1922 (N.A.I)

[6]. Singh Mohinder,(1988) The Akali Struggle, Retrospect,Atlantic pub,New Delhi p. 19, 20.

[7]. Singh Hari,Master Punjab Peasant in Freedom Struggle, volume two.pph New Delhi1984P106

[8]. SinghMohinder,(1977)The Akali Movement, National Institute Of Punjab Studies New Delhi,P 19,20

[9]. Singh Khushwant(1966), A History of the Sikhs, Vol. II, Oxford University Press, Bombay, p. 199

[10]. Singh Giani Partap, Gurdwara Sudhar Arthat Akali Lehar, p. 113

[11]. Sohan Singh Josh,(1977) Akali Morchian Da Itihas,Aarsi pub,Delhi pp. 70-71

[12]. Surinder Singh Johar (1998). Holy Sikh Shrines. M.D. PublicationsNew Delhi. p. 64

[13]. Bakhshish Singh Nijjar (1996). History of the United Panjab. Atlantic Publishers \& Dist. p. 130

[14]. S C Mittal (1977). Freedom Movement in Punjab. Concept.Anand nagar Delhi Concept pub,pp. 171-179.

[15]. Surinder Singh Johar (1998). Holy Sikh Shrines, M.D. Publications New Delhi p. 64.

[16]. S C Mittal (1977). Freedom Movement in Punjab, Anand Nagar Delhi Concept pub p. 171-179.

[17]. S C Mittal (1977). Freedom Movement in Punjab.Concept, Anand Nagar Delhi Concept pp. 171-179.

[18]. Singh Hari,Master Punjab Peasant in Freedom Struggle,volume two.pph New Delhi1984P112-113

[19]. Singh Hari,Master Punjab Peasant in Freedom Struggle,volume two.pph New Delhi1984P112-113

[20]. Singh Hari,Master Punjab Peasant in Freedom Struggle,volume two.pph New Delhi1984P112-113

[21]. Harbans Singh "The encyclopedia of Sikhism.

[22]. Harbans Singh "The encyclopedia of Sikhism.

[23]. Harbans Singh "The encyclopedia of Sikhism.

[24]. AKALIMOVEMENTCategory:Sikhreformistmovements(SikhEncyclopedia)http://www.thesikhenc yclopedia.com

[25]. Shiromani Gurdwara Parbandhak Committee From Wikipedia, the free encyclopedia

[26]. Shiromani Gurdwara Parbandhak Committee From Wikipedia, the free encyclopedia

[27]. Shiromani Gurdwara Parbandhak Committee From Wikipedia, the free encyclopedia

[28]. Singh Mohinder, (1988).The Akali Struggle, Retrospect,Atlantic publisher,New Dehi p. 19, 20. 